\title{
Designing online role plays with a focus on story development to support engagement and critical learning for higher education students
}

\author{
Mary Dracup \\ Deakin Learning Futures \\ Deakin University, Australia \\ mary.dracup@gmail.com
}

\begin{abstract}
Online role plays, as they are designed for use in higher education in Australia and internationally, are active and authentic learning activities (Wills, Leigh \& Ip, 2011). In online role plays, students take a character role in developing a story that serves as a metaphor for real-life experience in order to develop a potentially wide range of subject-related and generic learning outcomes. The characteristics of these stories are rarely considered as factors in the design-and success-of these activities. The unspoken cultural assumptions, norms and rules in the stories that impact on the meanings students make from their experiences are also rarely scrutinised in the online role play literature. This paper presents findings from a case study of an asynchronous text-based online role play involving politics and journalism students from three Australian universities. The findings highlight the centrality of students' collaborative story-building activity to their engagement and learning, including their development of critical perspectives. The study underlines the importance of certain aspects of the role play's design to support students' story-building activity.
\end{abstract}

Keywords

narrative, role play, online drama, critical literacy, higher education

\section{Introduction}

The story construct, in which an account is made of something that has happened, is recognised as a way in which people have made meaning from events since the earliest use of language. This simple and subtly persuasive construct is ubiquitous in social life, entertainment and education (Boyd, 2009; Egan, 1997). A story has three basic components: plot, setting and character. These components are discernible in stories in a wide range of formats including written, enacted, evoked or co-constructed with others in digital form (Ryan, 2006). An online role play can be seen as the collaborative building of an interactive dramatic story in which students take on character roles and develop a story plot in a given setting. Indeed, many other types of authentic learning activities make use of the construct when a real-life context is not practicable (Herrington, Reeves \& Oliver, 2010).

This paper demonstrates how online role plays can provide a methodology to better understand the ways in which the component parts work in isolation and together to engage their players and suggest meaning. Conceiving of the online role play (or indeed other authentic learning activity in a fictional setting with make-believe roles interacting in a meaningful way) as a story form also gives researchers and practitioners access to the considerable literature on story and narrative theory. This is a literature rich in insights for educators in how people become engaged in, and create meanings from, story structures (see, for example, Culler 1997, Herman \& Vervaeck, 2005; 
Ryan, 2006). This paper provides further analysis of an online role play case study described originally in two earlier publications (Dracup, 2009, 2010). Fuller detail on the literature review, methodology, and findings from this and two further case studies is available in Dracup (2011). The case study has particular relevance to the topic of "the borderless classroom" as it explores aspects of a technique that not only involves students from different disciplines in three universities but also gives students the means to generate their own text and images to tell their versions of the shared online role play stories.

\section{Background}

Online role plays are an increasingly popular teaching and learning technique used in higher education throughout the world (Wills et al., 2009). They involve students taking on the role of another person in a particular scenario and interacting with other role-playing students to explore an issue from the point of view of an insider. Students generally (but not always) interact through asynchronous text. As a group, online role plays are diverse, but the broad format has the following features:

- designed to increase understanding of real life human interaction and dynamics;

- participants assume a role in someone else's shoes or in someone else's situation;

- $\quad$ participants undertake authentic tasks in an authentic context;

- task involves substantial in-role interaction with other roles for collaboration, negotiation, debate;

- $\quad$ interaction between roles is substantially in an online environment;

- learning outcomes are assessable and generate opportunities for participant reflection

(Wills, Leigh \& Ip, 2011, p. 6)

This study draws on a wide range of literature including not only literary theory, but also learning, engagement, interactive multimedia and educational drama theory to develop a framework with which to analyse the ways in which the basic components of plot, setting and character might work most effectively in the particular format of online role plays. Key references include: Biggs and Tang (2007); Bolton and Heathcote (1999); Carroll, Anderson and Cameron (2006); Csikszentmihalyi (1990); Gee (2003, 2004); Herrington, Reeves and Oliver (2010); Murray (1997); O'Neill (1995); Vygotsky (1978); and Wills, Leigh and Ip (2011).

The framework consists of a set of conditions relating to the ways in which these components may be designed and managed in online, interactive, dramatic story-based activities to maximise students' engagement and learning according to principles and practices established in the various disciplines. The study also draws on critical literacy and critical pedagogy literature (see, for example, Cahill, 2008; Gregory \& Cahill, 2009; Misson \& Morgan, 2006; Rowan, 2001) to propose additional conditions that may be built into an online role-playing format to help students recognise, question and if necessary rework the unspoken cultural assumptions, norms and rules in these stories that impact on the meanings students make from their experiences. These conditions are listed below, along with an account of ways in which each has been provided in the case study that furnishes the context for this research.

\section{The case study}

The case study was a performance of the Middle East Politics Simulation (MEPS) that involved three Australian universities, sited in Victoria and New South Wales, which ran continuously over 
13 days during May 2009. This online role play was first performed in 1990 and has been repeated several times each year in Australian and international universities since then. It has been recognised as an exemplar of the online role play format (Wills \& Ip, 2002) and was also named as an exemplar of the internationalisation of teaching (Back, Davis \& Olsen, 1996) and a model of good practice in the use of information technologies in international education (Alexander \& Blight, 1996). In the role play, students of political science from two of the universities formed groups of two or three and took roles as key players in Middle-Eastern politics. Some of these groups contained a mix of students from different universities communicating only by electronic means.

Students were given a fictitious scenario containing a dramatic mix of bombings, kidnappings, high-level political manoeuvrings and other diplomatic incidents. They then used simulated email to respond to these events from the perspective of their characters and plan additional fictional actions. Journalism students from the third university emailed questions and reported on the politics characters' activities in vivid detail in three different daily online newspapers, each reflecting real-life newspapers from different countries in their style and editorial bias, and including colourful pictures to bring the characters and actions alive.

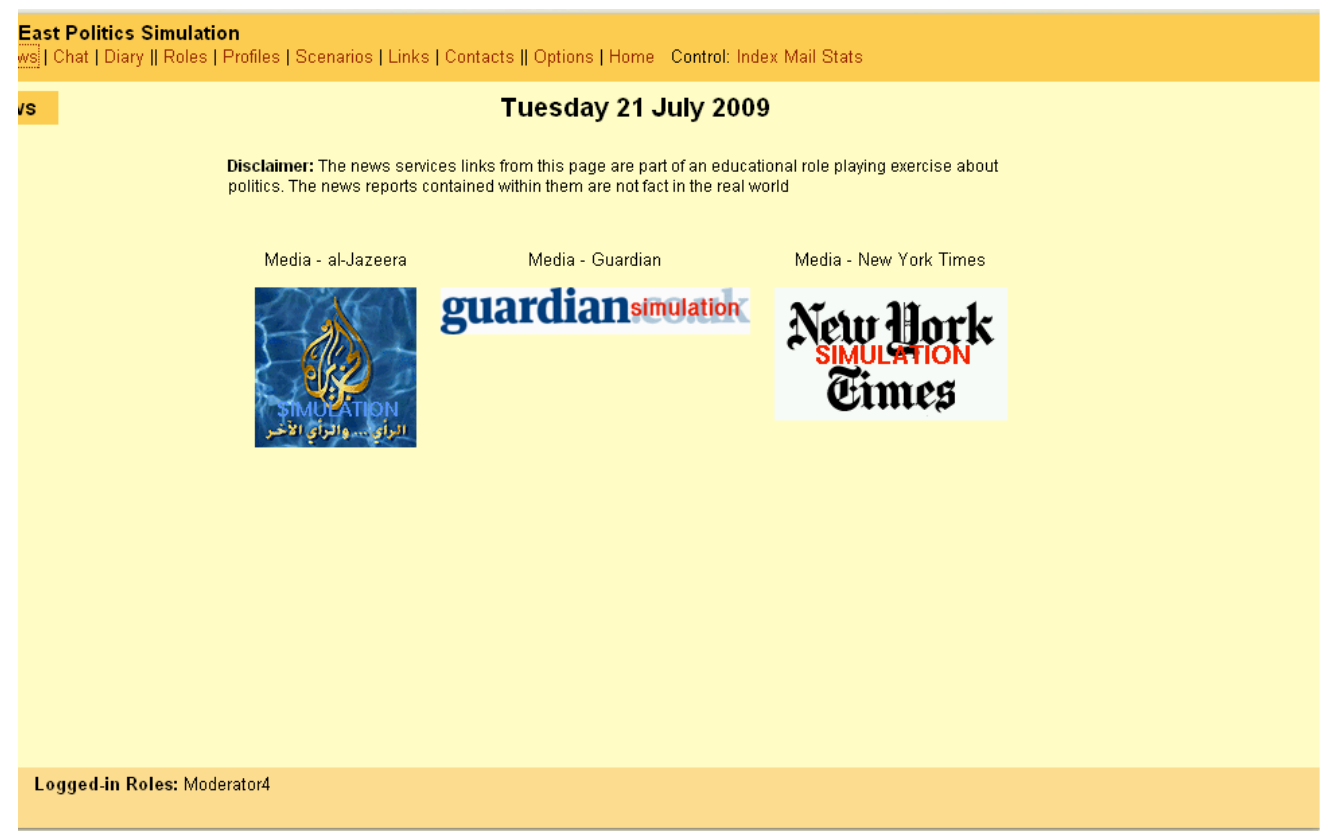

Figure 1. The Middle East politics simulation (MEPS) home page (screen shot)

The newspapers (in this case, Al Jazeera, The Guardian and the New York Times) provided a builtin reflective device that also gave the politics students a taste of how news media worked to create representations of reality. A purpose-built website (see Figure 1) provided access to the online newspapers and email accounts, and hosted the rich and multi-faceted stories that the students developed (see Figure 2). 


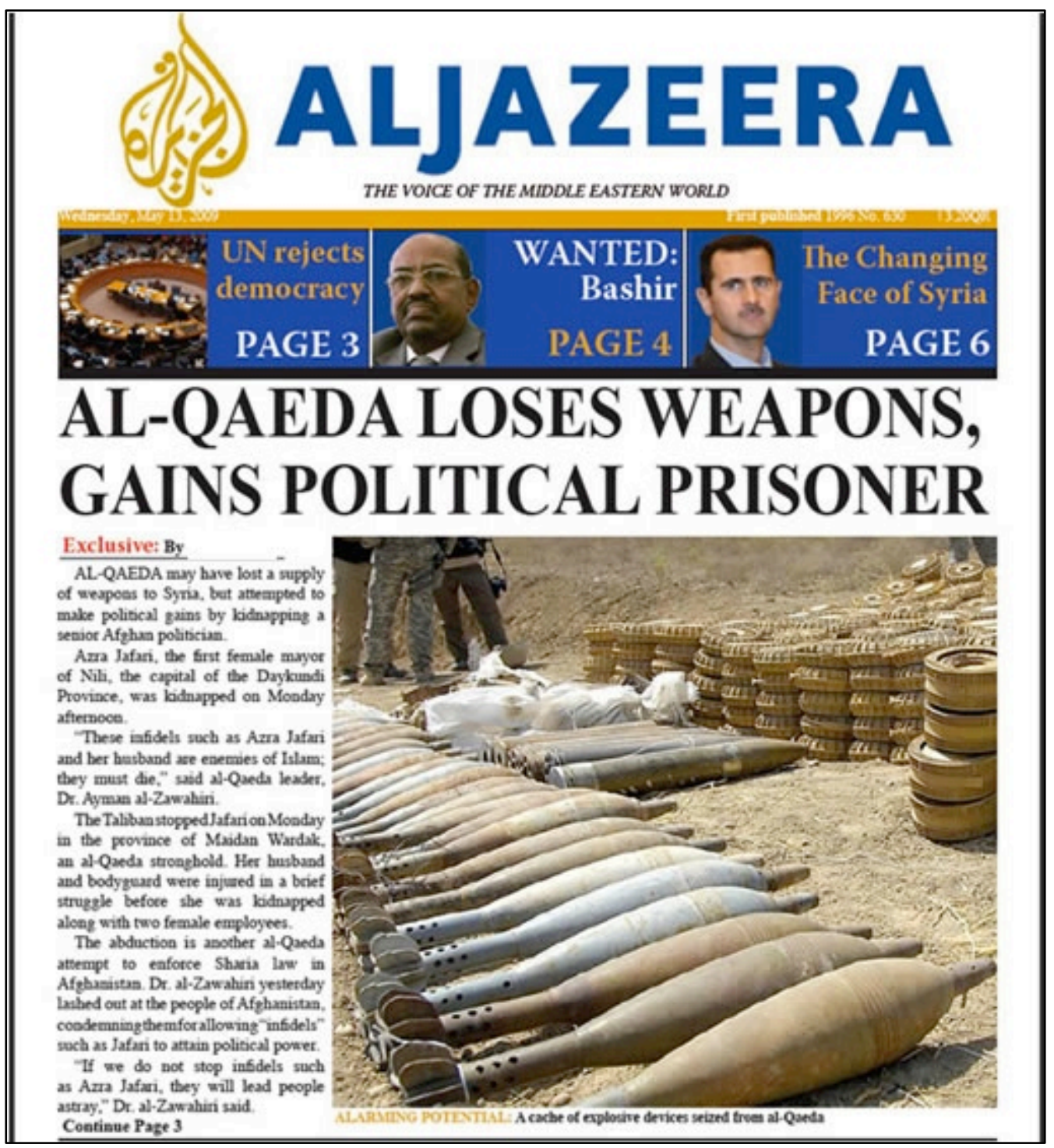

Figure 2. An example of an online newspaper front page (student names obscured)

On the last day, players who were located close to one of the universities "confronted" each other in a face-to-face conference to debate their positions. Students were assessed on the quantity and quality of their postings, the character profile they posted on the site before the start of the role play, and the position paper they presented at the concluding conference. Although students were encouraged to be creative in their strategies, an important assessment criterion was that they behave according to what was plausible for whichever real-life character they were representing.

\section{Method}

Table 1 provides the framework of conditions, derived from the literature, which was used to help analyse the data gathered in this case study. 
Table 1. Conditions to support engaging and meaningful story development and critical learning outcomes in online role plays

\begin{tabular}{|c|c|c|}
\hline $\begin{array}{l}\text { Story } \\
\text { element }\end{array}$ & Conditions & Description \\
\hline \multirow[t]{4}{*}{ Plot } & $\begin{array}{l}\text { Causal links } \\
\text { between events }\end{array}$ & $\begin{array}{l}\text { Participants need to be able to discover probable linkages between character } \\
\text { traits, actions and outcomes in the story world, to develop useful mental } \\
\text { models that they can use to guide future thoughts and actions. }\end{array}$ \\
\hline & Identifiable genre & It helps to be able to identify a genre, to build expectations and tension. \\
\hline & $\begin{array}{l}\text { Agency within } \\
\text { bounds }\end{array}$ & $\begin{array}{l}\text { A balance is needed between giving students the opportunity to decide how } \\
\text { their character will influence events, and engineering the kinds of interactions } \\
\text { that might help them manage tension and build useful mental models. }\end{array}$ \\
\hline & Critical learning & $\begin{array}{l}\text { Critical learning may be fostered by limiting generic plot development or } \\
\text { interrupting and challenging plots that might otherwise carry unquestioned } \\
\text { ideological assumptions and values. It may also be fostered by encouraging } \\
\text { students to rework plots to suggest meanings that are more aligned with a } \\
\text { considered stance. }\end{array}$ \\
\hline \multirow[t]{6}{*}{ Character } & $\begin{array}{l}\text { Consistent } \\
\text { representation }\end{array}$ & $\begin{array}{l}\text { The roles should represent something within the simulated system-they are } \\
\text { not just people. They should be developed consistently, so that they help } \\
\text { students learn how things work in the social system that is represented. }\end{array}$ \\
\hline & Supports empathy & $\begin{array}{l}\text { It is important for students to be able to identify sufficiently with their } \\
\text { character roles that they can develop empathy for them. This enables them to } \\
\text { learn vicariously from their characters' experiences as an extension of } \\
\text { themselves playing within the possibilities of the story world, and to care about } \\
\text { what happens }\end{array}$ \\
\hline & Agency & $\begin{array}{l}\text { Students should be given agency in their roles so that they feel a sense of } \\
\text { challenge and potential reward, control over outcomes and an opportunity to } \\
\text { extend themselves beyond normal limitations. }\end{array}$ \\
\hline & $\begin{array}{l}\text { Safety to } \\
\text { experiment }\end{array}$ & It is important for students to feel safe to experiment in character. \\
\hline & Supports metaxis & $\begin{array}{l}\text { Students should be prompted to reflect on their role playing and how it relates } \\
\text { to their previous conceptions, experience and behaviour. }\end{array}$ \\
\hline & Critical learning & $\begin{array}{l}\text { Students should be prompted to understand and play their roles as complex, } \\
\text { multi-faceted characters rather than as stereotypes. They should also } \\
\text { experience the need to understand underlying cultural characteristics of } \\
\text { opposing roles in taking action to resolve differences during the role play. }\end{array}$ \\
\hline \multirow[t]{6}{*}{ Setting } & $\begin{array}{l}\text { Coherence and } \\
\text { plausibility }\end{array}$ & $\begin{array}{l}\text { There must be a sense of the internal coherence and plausibility of the way } \\
\text { things work in the story world, in order to support students' suspension of } \\
\text { disbelief and building of useful mental simulations for future reference. }\end{array}$ \\
\hline & Authenticity & $\begin{array}{l}\text { Authenticity in key aspects of the tasks and conditions of the real-world setting } \\
\text { that is simulated is important to provide a sense of relevance and support } \\
\text { application of learning in real situations. }\end{array}$ \\
\hline & $\begin{array}{l}\text { Rich visual detail } \\
\text { and information }\end{array}$ & $\begin{array}{l}\text { Providing rich visual detail and information can produce a sense of } \\
\text { enchantment and presence in the virtual world. }\end{array}$ \\
\hline & $\begin{array}{l}\text { Transparent, } \\
\text { responsive } \\
\text { interface }\end{array}$ & $\begin{array}{l}\text { An interface will better support both engagement and learning if users are } \\
\text { orientated to the site and tasks early on, and if the interface enables users to } \\
\text { interact with it in exactly the ways they want and gain predictable results. }\end{array}$ \\
\hline & $\begin{array}{l}\text { Semi-permeable } \\
\text { boundary from } \\
\text { reality }\end{array}$ & $\begin{array}{l}\text { It is important for students to have a sense that they are in a make-believe } \\
\text { world with a boundary from reality (albeit a porous one). }\end{array}$ \\
\hline & Critical learning & $\begin{array}{l}\text { Students should be encouraged to recognise, critique and if possible rework the } \\
\text { cultural assumptions embedded in the setting and ways in which these } \\
\text { influence the meanings that are suggested in the stories. }\end{array}$ \\
\hline
\end{tabular}


The study involved mixed methods of data collection, from multiple sources. Methods included questionnaires with open and closed (five-point Likert scale) questions, focus groups, interviews and analysis of online postings. The methods and numbers of participants for each are set out in Table 2. As the number of journalism student participants was very small, the study focused mainly on the experience of the politics students. The study was approved by the Deakin University Human Research Ethics Committee.

Table 2. Data collection methods and participants

\begin{tabular}{|c|c|c|c|c|c|}
\hline Cohort & $\begin{array}{c}\text { Consenting } \\
\text { participants } \\
\text { (students in } \\
\text { cohort) }\end{array}$ & $\begin{array}{l}\text { Groups } \\
\text { observed } \\
\text { (via online } \\
\text { postings) }\end{array}$ & $\begin{array}{l}\text { Questionnaire } \\
\text { respondents }\end{array}$ & $\begin{array}{l}\text { Focus group } \\
\text { participants }\end{array}$ & $\begin{array}{c}\text { Interview } \\
\text { participants } \\
\text { (email, } \\
\text { telephone or } \\
\text { face-to-face) }\end{array}$ \\
\hline $\begin{array}{l}\text { Middle East } \\
\text { Politics } \\
\text { (undergraduates) }\end{array}$ & $\begin{array}{l}43 \\
(66)\end{array}$ & 11 & 14 & 3 & $\begin{array}{l}11 \text { students, } \\
1 \text { lecturer }\end{array}$ \\
\hline $\begin{array}{l}\text { Middle East } \\
\text { Politics } \\
\text { (Masters-level) }\end{array}$ & $\begin{array}{c}3 \\
(26)\end{array}$ & - & 7 & - & 1 lecturer \\
\hline $\begin{array}{l}\text { Journalism } \\
\text { (undergraduates) }\end{array}$ & $\begin{array}{c}2 \\
(27)\end{array}$ & - & - & - & 1 student \\
\hline Totals & $\begin{array}{c}48 \\
(119)\end{array}$ & 11 & 21 & 3 & 14 \\
\hline
\end{tabular}

\section{Findings and discussion}

Many of the students participating in this online role play indicated in their questionnaires, interviews or focus group that they had achieved strong learning outcomes. These outcomes could be seen to be linked directly to their high engagement with building stories collaboratively in the simulated world. There were indications that each of the conditions investigated in the analysis contributed to these results.

\section{Learning outcomes}

The role play was designed and used with the aim of helping students learn the facts of Middle Eastern politics, the complexities of political negotiation and decision making, and a range of generic skills (Vincent \& Shepherd, 1998; Lecturer 1 interview). Of the (political science) student questionnaire respondents, $95 \%$ agreed or strongly agreed that, as a result of the activity, they had "a better understanding of the facts of Middle East politics"; and 89\% agreed or strongly agreed that they "better understand the complexities of negotiation and decision-making in real political systems." In a further question on improvement of generic skills (as listed by Deakin University 2009), at least half of the respondents indicated they had improved in all of the skills listed, and several skills were indicated by more than $80 \%$. The highest scoring skills were: identifying, evaluating and using information; creative thinking; problem solving; communicating in a different context; working effectively as part of a team; and effectively using information and communication technologies. Several of the political science students' comments were extremely enthusiastic about their learning from the MEPS, for example: 
The sim is the best thing I've ever done in tertiary education. It gives you a real opportunity for creative learning, problem solving, teamwork and so on but also makes you find out about the intricacies of the political situation (Liz, interview).

Developing students' critical awareness of cultural assumptions and values in Middle-Eastern politics and their ability to have a voice and make a difference in this arena were not mentioned among the learning aims of the MEPS. However, $89 \%$ of questionnaire respondents said they were more likely to question stereotypes, Western assumptions and media representations of players and issues in Middle-Eastern politics as a result of taking part in the activity. An enhanced awareness of the ways in which news media constructed a spurious representation of reality that was frequently stereotyped and advantaged some while disadvantaging others was a further learning outcome mentioned by several of the interviewees.

There were many indications in my data that the MEPS provided conditions for a zone of proximal development (Vygotsky, 1978) for the students to learn the intended-and also unintended-skills, knowledge and attitudes outlined above. Interviewees said they breached the gap in knowledge that they initially faced in terms of factual and procedural knowledge and generic skills through accessing "more knowledgeable others" in the form of web-based resources, their group-mates and their lecturers. They also had opportunities to experiment with, refine and consolidate their knowledge through their role playing with feedback from other roles, as well as through seeing the ways in which their actions were represented in the online newspapers. In addition, many commented that the role play provided opportunities to learn about the constructedness and fallibility of news reports, how injustices are perpetrated and promoted through news media, and how media organisations may be managed to increase the possibility of having one's view published. It is notable for this research that these learning outcomes were strongly connected with the students' motivation to develop their characters and create interesting plots within the setting of their make-believe world.

\section{Engagement}

Of the questionnaire respondents, $90 \%$ said they had been either "totally immersed" or "highly engaged" in the online role play. All said they had enjoyed it. Several said the activity had been "at the back of their mind" throughout the 13 days, and more than one spoke of dreaming about it (Jen, Ciaran (focus group); Dan, Kerry, Jeremy (interviews)). Some described their engagement in similar terms to those commonly used to describe "flow" (Csikszentmihalyi, 1990) and engagement with video games (Gee, 2003). For example, Dan said he seemed to have "tuned out of the real world" and the role play had become his reality. Another commented:

It draws you in and immerses you very quickly. You certainly don't feel it doesn't matter if things go badly for you in the sim. For example, things have just gone a bit badly for us in the sim and we're feeling pissed off, and want to get the problem fixed as quickly as possible (Sam, interview).

Students' responses to questionnaire, focus group and interview questions indicated that the MEPS provided many factors of engagement (Barkley, 2010; Biggs \& Tang, 2007; Csikszentmihalyi, 1990; Gee, 2003). These included the extrinsic factors of assessment, relevance to life goals, group membership and competition; and factors supporting intrinsic engagement such as a strong challenge-support balance, with feedback built into the interactions and a sense of a convenient, safe environment for experimentation. However, none of these factors operated independently in the activity, but worked together with others to support the students' performance of the central task of promoting their character's position in the numerous story plots in the simulated setting. Thus, there were numerous indications that supporting the students' development of stories in this activity helped them to not only engage with the activity but to achieve important learning outcomes. Many students described a feedback loop in which the more they engaged with developing strategies to advance their character, the more they learned about their character and 
the Middle-Eastern context, and the more satisfaction they received at seeing their character succeed. Then the more they learned, the more possibilities they discovered for further strategies, engagement, satisfaction and learning (Dan, Liz, Sam, Briony, Jeremy (interviews); Thierry, Jen, Ciaran (focus group)). The specific conditions supporting engagement, meaning creation and critical learning operated in the following ways in this online role play.

\section{Conditions relating to plot}

\section{Causal links between events}

Students were free to construct events in the simulated world but, to receive high marks, they were obliged to act according to the pre-existing traits of their character and the real Middle-Eastern setting. Their lecturers - in role as a Control character - used the same criterion when deciding whether to allow proposed strategies. Therefore, the plots developed largely according to the classic story structure of actions caused by the interaction of characters with certain pre-existing traits within the parameters of the setting (Aristotle 350BC/Halliwell, 1986; Murray, 1997). In so doing, the plots supported the students' ability to build generalisations based on what was likely to happen given certain character traits in a given situation (Gee, 2004). In their questionnaire responses, students listed numerous principles they had learned relating to Middle Eastern politics-and politics in general-from their experiences in the simulated world. These included: don't negotiate with rogue states; if armed with enough information you can outmanoeuvre your opponent; keep your enemies close; and, violent terrorism will not make a country acquiesce to your demands, but negotiation does have a chance.

\section{Identifiable genre}

Many students indicated, through their comments, that they had experienced a similar type of immersion in the role play as they sometimes gained with games in the classic heroic adventure genre that is common in action movies and video games (Gee, 2003; Murray, 1997). With the extreme pre-existing traits of many of the characters, it was within the bounds of plausibility that many of their interactions would be filled with angry and violent confrontations and dramatic intrigues. In addition, many participants commented that the sense of competition that is common to the heroic adventure genre provided an extra source of motivation to research and work hard as a means to advance their heroic character's interests. For example:

\section{It was like a game - so it was heaps of fun. And there was an element of challenge trying to figure out different strategies and working with partners to, you know, try and win, basically (Thierry, focus group).}

\section{Agency within bounds}

The students had strong incentives to not only respond to events but to create their own events in the role play and hence learn from their experiments in the simulated world (Gee, 2004). As well as being assessed on the quality of messages they sent in character, they were assessed on the quantity of their postings. Lecturers provided suggestions for strategies to less active participants. If the political science students could create events that the journalism students deemed newsworthy, they would gain additional kudos by being reported in the online newspapers. There were many comments that students enjoyed the opportunity to use their creativity to construct these events and that it motivated them to learn to work with their group-mates and to research many aspects of Middle-Eastern politics. As well, students were keenly aware of the ways in which their strategies were reported and responded to by other characters in their emails, which gave them intrinsic feedback on their work. However, the role play was facilitated in such a way as to maintain a balance between giving the students these opportunities to experiment and imposing constraints to ensure their stories afforded aesthetic interest and meaning (Ryan, 2006). Students' wilder ideas were tempered by the requirement to seek the approval of their Control (lecturer) for 
strategies that were out of the ordinary, and Control periodically leaked potentially explosive pieces of information to key players to add interest. The Site 1 Lecturer did not control events obsessively, rather, she allowed a significant degree of confusion to develop without stepping in to resolve it, saying that this gave the students a taste of the difficulty for anyone to interpret events and establish "truth" in the Middle East (Lecturer 1 interview).

\section{Critical learning}

Student comments revealed they had learned, through the coverage provided by the online newspapers, about how news media organisations presented a distorted representation of events due to their desire to deliver "newsworthy" and politically acceptable reports to their readership whether they were readers of Al Jazeera, The Guardian or the New York Times. Many students complained about how plots involving terror, armed conflict and tirades routinely received prominence at the expense of efforts they themselves had been making to pursue careful diplomatic negotiations to promote peace and social justice; and how these reports varied considerably depending on the newspaper's point of view. Many also recounted instances they had noticed in which inaccurate or irresponsible media reports had inflamed difficult situations.

\section{Conditions relating to character}

\section{Consistent representation}

The assessment criterion that students act in ways that were realistic for their real-life character provided an incentive for students to portray their characters consistently. A further assessment requirement was for students to prepare a profile of their character before the role play started and post this publicly on the website. Most questionnaire respondents indicated that preparing the profile had helped them understand how each character should act and what they stood for (Misson $\&$ Morgan, 2006). Having these profiles posted on the website meant all students could access them when they needed to learn more about each other's characters. Students relied on each other's characters behaving consistently so they could prepare strategies involving others that had a reasonable chance of success.

\section{Supports empathy}

Students were given incentives through their assessment to get to know their characters well, including values, backgrounds and motivations, as noted above. Even though many of the political characters held extreme views making them difficult to identify with, almost all of the students said they had been able to empathise with their characters. There were indications in many comments that, in projecting a representation of their character and gaining intrinsic feedback on their projection through other characters' responses, students had the opportunity to learn about themselves as well. For example:

My goals were to play in my character, do what they would do in real life and think the way they do. Interestingly, I got to think the way they think. i.e., Zawahiri, a terrorist, has his own ideology which he perpetuates by using force and inciting fear rather than negotiation (questionnaire comment).

There were also indications in students' comments that, by experiencing the development of these characters through the role play events, they were enabled to experience the pleasure and deep insight afforded by reflexive learning (Gee, 2003; O’Neill, 1995).

\section{Agency}

Although, theoretically, the students had considerable agency in their simulated world, the extent to which a fairly large proportion could create events and interact with other characters-and 
hence gain the direct benefits of extending their normal range of behaviour and receiving intrinsic feedback on their performance-was in fact constrained by the nature of the characters they were playing. For example, terrorists and spies realistically would have little direct contact with most politicians, and foreign and defence ministers were obliged to wait for the approval of their president before enacting radical strategies. On the other hand, students playing central roles such as Obama and Netanyahu were swamped with so many emails and opportunities that they found it challenging just to keep up. A significant number of students commented that their character role limited their agency in the simulated world and that this was frustrating. In addition, it would have limited the strength of the feedback loop these students might have developed between engagement, activity and learning.

\section{Safety to experiment}

Students had the protection of a role that was clearly different to their usual identity; and the anonymity and extra time to think and research that came with communicating via asynchronous text, and being part of a group. There were no indications in students' comments or postings that they felt inhibited to act in role; indeed, the outrageous plots that some created showed that they felt free to extend themselves in their roles. Several comments indicated that students appreciated the various levels of protection and distance (Carroll, Anderson \& Cameron, 2006) afforded by the fact that their interactions took place on an online, asynchronous text platform, with the reassurance and added anonymity afforded by a group.

\section{Supports metaxis}

Although the lecturers did not provide explicit guided reflection activities, which are a common way to ensure students make connections between the story world and the real world (Bolton \& Heathcote, 1999), the incentives for students to act according to what was credible for their character should have prompted them to reflect on how their role playing paralleled reality. Also, many said they discussed the realism and feasibility of their strategies with their group-mates. In addition, as mentioned above, there were indications that the online newspapers' distorting mirror on the simulated world prompted students to reflect on the ways in which "truth" was represented in the role play and how closely this reflected the ways in which news media worked in real life.

\section{Critical learning}

Students' characters included a mix of many non-middle-class, non-middle-aged, non-European, non-Christian roles that differed from the dominant roles in Australia. Several students' comments indicated that representing minority-group perspectives over an extended period had broadened their perspectives and deepened their understanding of the difficulties facing these people in trying to make their voice heard (Rowan, 2001).

\section{Conditions related to setting}

\section{Coherence and plausibility}

The students mainly used the chaotic multi-vocal array of "real" information resources on the World Wide Web to build their stories. However, the assessment criterion that they act according to the traits of their real character, established in their research for their profile assessment piece-and to check with Control before enacting strategies that were out of the ordinary-ensured that most of the events remained both plausible for the Middle-Eastern setting and coherent within the role play. There is evidence in students' comments that the level of coherence and plausibility established for this setting was sufficient to enable them to build robust and useful mental simulations from their experience (Gee, 2004). 


\section{Rich visual detail and information}

While the interface in which students interacted was minimalist, the online newspapers produced by the journalism students provided both visual stimulation and almost daily information on what was going on in the simulated world, supporting the development of a rich learning context (Gee, 2004). The MEPS designer had little control over the actual imagery and information that was used to build the setting for the stories. However, the contributions of appropriately skilled journalism students-who were also assessed on their ability to act "in character" as newspaper staff-co-developing the scenario with articles and other features that were as authentic as they could make them, ensured that the stories had a reasonable degree of both realism and aesthetic appeal.

\section{Transparent, responsive interface}

The boundary between the MEPS and the real world appeared strong but proved quite porous (Cahill, 2008). Students researched real-world information sources to learn how to act according to the traits and background of their character in the setting. As a result, many said they experienced confusion separating the events building in the role play from those occurring in the real Middle East. While students invented many outrageous actions in the simulation without the fear that anything catastrophic would really happen, an incident in which a student's text message telling of a planned bombing was sent to an outsider, resulting in the Federal Police temporarily shutting the role play down, provided an edgy sense of realism that emphasised the thinness of this boundary.

\section{Authenticity}

Almost all of Herrington, Reeves and Oliver's (2010) characteristics of "authentic tasks" were provided in the MEPS. Students' assessment criterion to act in character, as well as the incentives that were present for them to produce the kinds of actions that would gain them visibility in the online newspapers, meant they had to learn quickly not only what was possible for their character to do in the context but also learn to negotiate from a particular perspective, manage conflict, work with their group-mates and manage the media in much the same ways as real politicians did. If they did not manage their tasks well, students faced authentic consequences in terms of criticism in the online newspapers or the invisibility of not being reported on at all, as well as penalisation in their assessment.

\section{Critical learning}

Many participants complained of biased, inaccurate and sometimes irresponsible reporting impacting on how their stories were represented in the online newspapers. These comments indicated that they had reflected at some level on how meanings could be embedded in the parameters governing interactions in an online role play. However, the lecturers did not intervene to highlight the cultural assumptions that were promoted and encourage students to think about how these might be challenged or address these issues in a debriefing session, as is recommended practice in educational drama activities (Cahill, 2008; O’Neill, 1995). I believe more advantage could have been taken of this opportunity to promote critical learning outcomes.

\section{Conclusion}

These findings indicate that most—but not all-of the conditions identified in the literature as promoting student engagement, meaning-making and critical learning in online role play stories were well provided for in the MEPS. There were strong indications that these conditions had indeed worked to support many students' motivation and ability to co-develop interesting stories in which their character succeeded. Where the conditions were not supported particularly well, for 
example, in the limited agency that some students experienced due to the nature of the character they were playing, students expressed frustration. The fact that strong engagement, learning and critical learning outcomes were able to be achieved in the MEPS, even though some of these conditions had been supported less well than was ideal, indicates that it may not be necessary to provide all of the conditions; perhaps a critical mass of them is sufficient to produce strong engagement and learning outcomes.

To my knowledge, this study represents the first attempt at applying a cross-disciplinary methodological framework of this type to analyse the ways in which students become engaged with, create meaning from, and develop critical learning outcomes from an online role play. Further research is called for to confirm and perhaps refine or extend the framework. As each online role play has unique characteristics, wider studies involving numbers of online role-playing activities would be useful as would longitudinal studies to gather indications of long-term impacts of these activities. In the meantime, the findings suggest that the framework of conditions that has been proposed provides a useful methodology, grounded in a wide-ranging literature and evolving story-telling tradition, on which to base the design and analysis of online role-playing activities.

\section{References}

Alexander, S., \& Blight, D. (1996). Technology in international education, $10^{\text {th }}$ Australian International Education Conference, Adelaide.

Aristotle 350BC/Halliwell, S. (1986) Aristotle's poetics. Chapel Hill, NC: University of North Carolina Press.

Back, K., Davis, D. \& Olsen, A. (1996). Internationalisation and higher education: goals and strategies, Report 96/15, Commonwealth Department of Employment, Education, Training and Youth Affairs, Canberra.

Barkley, E. (2010) Student engagement techniques: A handbook for college faculty. San Francisco, CA: Jossey-Bass.

Biggs, J., \& Tang, C. (2007). Teaching for quality learning at university. Buckingham, UK: Open University Press/McGraw Hill.

Bolton, G., \& Heathcote, D. (1999). So you want to use role play? Stoke on Trent, UK: Trentham.

Boyd, B. (2009). On the origin of stories. Cambridge, MA: Harvard University Press.

Burbules, N. (2004). Rethinking the virtual. E-Learning, 1(2), 162-83.

Cahill, H. (2008). Learning partnerships: The use of poststructuralist drama techniques to improve communication between teachers, doctors and adolescents. Unpublished Ph.D. Thesis, University of Melbourne, Australia.

Carroll, J., Anderson, M. \& Cameron, D. (2006). Real players? Drama, technology and education. Stoke on Trent, UK: Trentham.

Csikszentmihalyi, M. (1990). Flow: The psychology of optimal experience. New York: Harper Perennial.

Culler, J. (1997). Literary theory: A very short introduction. New York: Oxford University Press.

Deakin University. (2009). Graduate attributes at Deakin. Institute of Teaching and Learning, Deakin University. Retrieved from http://www.deakin.edu.au/itl/pd/tlmodules/curriculum/grad-attrib/grad-attr-02.php

Dracup, M. (2009). Story as a vehicle for learning in online role play: A case study. Paper presented to AARE Conference, Canberra, December. Retrieved from http://www.aare.edu.au/09pap/dra091362.pdf 
Dracup, M. (2010). Reshaping dominant stories: A poststructuralist approach to online role play. Paper presented to HERDSA Conference, Melbourne, July. Retrieved from http://conference.herdsa.org.au/2010/program/concurrent4.html\#dracup

Dracup, M. (2011) Online role play stories, engagement and learning in higher education. Unpublished PhD thesis, Deakin University. Retrieved from http://dro.deakin.edu.au/view/DU:30042602

Egan, K. (1997) The educated mind: How cognitive tools shape our understanding. Chicago, IL: University of Chicago Press.

Gee, J. (2003). What video games have to teach us about learning and literacy, New York: Palgrave Macmillan.

Gee, J. (2004). Situated language and learning. New York: Routledge.

Gregory, A., \& Cahill, M. (2009). Constructing critical literacy: self-reflexive ways for curriculum and pedagogy, Critical literacy: Theories and practices, 3(2), 6-16.

Herman, L., \& Vervaeck, B. (2005). Handbook of narrative analysis. Lincoln, NE: University of Nebraska Press.

Herrington, J., Reeves, T. \& Oliver, R. (2010). A guide to authentic e-learning. London: Routledge.

Misson, R., \& Morgan, W. (2006). Critical literacy and the aesthetic: Transforming the English classroom. Urbana, IL: National Council of Teachers of English.

Murray, J. (1997). Hamlet on the holodeck: The future of narrative in cyberspace. Cambridge, MA: MIT Press.

O'Neill, C. (1995). Drama worlds: A framework for process drama. Portsmouth, NH: Heinemann.

Rowan, L. (2001). Write me in: Inclusive texts in the primary classroom. Newtown, NSW: Primary English Teaching Association.

Ryan, M. (2006). Avatars of story. Minneapolis, MN: University of Minnesota Press.

Vincent, A., \& Shepherd, J. (1998). Experiences in teaching Middle East politics via Internetbased role play simulations. Journal of Interactive Media in Education, November.

Vygotsky, L. (1978). Mind and society: The development of higher mental processes. Cambridge, MA: Harvard University Press.

Wills, S. \& Ip, A. (2002). enRole, research, react, resolve, reflect: developing and using online role play learning designs. Retrieved from http://www.learningdesigns.uow.edu.au/guides/info/g1/index.htm

Wills, S., Leigh, E. \& Ip, A. (2011). The power of role-based e-learning. London: Routledge.

Wills, S., Rosser, E., Devonshire, E., Leigh, E., Russell, C. \& Shepherd, J. (2009). Encouraging role based online learning environments by building, linking, understanding, extending: The BLUE report. Australian Learning and Teaching Council, Strawberry Hills, NSW.

\section{Acknowledgement}

This study was funded with a Deakin University Doctoral Scholarship. 